\title{
Best Practice Kepemimpinan Kepala Sekolah dalam Menciptakan Iklim Belajar Jarak Jauh yang Kondusif
}

\author{
Retno Miasih, Enung Hasanah* \\ Program Studi Magister Manajemen Pendidikan, FKIP, Univeristas Ahmad Dahlan \\ *Corresponding Author. Email: enung.hasanah@mp.uad.ac.id
}

\begin{abstract}
This study aims to explore the leadership style of the principal at SD Muhamamdiyah 2 Blawong in creating a conducive learning climate during learning from a distance amids the pandemic covid-19. This study used a descriptive method with a qualitative approach. The research subjects consisted of principals, school committees, classroom teachers, and parents. Data collection techniques were carried out through in-depth individual interviews, environmental observations, and document analysis. All data collected were analyzed using qualitative analysis methods. Based on the results of the study, it could be seen that the learning climate implemented at SD Muhammadiyah Blawong 2 was very conducive to learning from a distance. The results of this study indicate that it was inseparable from the leadership role of the school principal who was adaptive, prioritized cooperation, fair, and has the perfect attitude to build a conducive learning climate. This was also inseparable from the ability of the principal in getting support from the parents of students. Therefore, school principals should always try to increase creativity in adapting any changes that occur.
\end{abstract}

\begin{abstract}
Abstrak: Penelitian ini bertujuan untuk mengeksplorasi tentang gaya kepemimpinan kepala sekolah di SD Muhamamdiyah 2 Blawong dalam menciptakan iklim belajar yang kondusif pada pembelajaran jarak jauh selama masa pandemi Covid-19. Penelitian ini menggunakan metode deskriptif dengan pendekatan kualitatif. Subjek penelitian terdiri dari kepala sekolah, komite sekolah, guru kelas, dan orang tua siswa. Teknik pengumpulan data dilakukan melalui wawancara individu mendalam, observasi lingkungan, dan analisis dokumen. Semua data yang dikumpulkan dianalisis menggunakan metode analisis kualitatif. Temuan penelitian ini menunjukan bahwa iklim pembelajaran yang dilaksanakan di SD Muhammadiyah Blawong 2 sangat kondusif untuk pembelajaran jarak jauh. Hal ini menunjukkan bahwa tidak terlepas dari peran kepemimpinan kepala sekolah yang adaptif, mengutamakan kerjasama, adil, dan memiliki sikap yang sempurna untuk membangun iklim pembelajaran yang kondusif. Hal tersebut juga tidak terlepas dari kemampuan kepala sekolah dalam medapatkan dukungan dari para orang tua siswa. Oleh karena itu, hendaknya setiap kepala sekolah selalu berupaya meningkatkann kreativitas dalam menghadapi setiap perubahan yang terjadi.
\end{abstract}

\section{Article History}

Received: 11-03-2021

Revised: 03-05-2021

Accepted: 26-07-2021

Published: 07-09-2021

\section{Key Words:}

Best Practice, Leadership, Conducive Learning

Climate, Elementary

School, Distance Learning.

\section{Sejarah Artikel}

Diterima: 11-03-2021

Direvisi: 03-05-2021

Disetujui: 26-07-2021

Diterbitkan: 07-09-2021

\section{Kata Kunci:}

Best Practice, Kepemimpinan, Iklim Belajar Kondusif, Pembelajaran Jarak Jauh.

How to Cite: Miasih, R., \& Hasanah, E. (2021). Best Practice Kepemimpinan Kepala Sekolah dalam Menciptakan Iklim Belajar Jarak Jauh yang Kondusif. Jurnal Kependidikan: Jurnal Hasil Penelitian dan Kajian Kepustakaan di Bidang Pendidikan, Pengajaran dan Pembelajaran, 7(3), 565-575. doi:https://doi.org/10.33394/jk.v7i3.3559

https://doi.org/10.33394/jk.v7i3.3559

This is an open-access article under the CC-BY-SA License.

\section{Pendahuluan}

Bahaya penularan Covid-19 sudah menyebar ke seluruh dunia termasuk Indonesia. Hal tersebut menjadi kekhawatiran tersendiri bagi Pemerintah Republik Indonesia, termasuk bagi kalangan dunia pendidikan (Citra Resmi \& Hasanah, 2020; Hasim \& Hasanah, 2020). Untuk menekan penyebaran Covid-19 di kalangan pelajar, pemerintah pusat mengeluarkan 
kebijakan belajar dari rumah. Berdasarkan surat edaran menteri kesehatan nomor : PK.02.01/B.VI/839/2020 dan edaran menteri Pendidikan dan kebudayaan nomor 3 tahun 2020 tentang pencegahan corona virus disease (Covid-19) serta intruksi Gubernur Daerah Yogyakarta nomor : 2/INSTR/2020 tanggal 3 maret 2020 tentang peningkatan kewaspadaan terhadap risiko penular infeksi corona virus disease (Covid-19) maka Dinas Pendidikan, Pemuda dan Olah raga mengeluarkan keputusan nomor : 21/02280 tentang himbauan upaya pencegahan penularan Covid-19. Kepala sekolah sebagai pemimpin membuat kebijakan melaksanakan sistem pembelajaran jarak jauh mulai tanggal 23 maret 2020 secara daring, sesuai edaran dari pemerintah (Herliandry \& Suban, 2020).

Menjelang tahun ajaran baru 2020/2021, pemerintah menentukan sikap untuk new normal, tetapi dunia pendidikan masih menyelenggarakan pembelajaran jarak jauh, termasuk di SD Muhammadiyah Blawong 2 Bantul, Yogyakarta. Hal tersebut dilakukan berdasar keputusan bersama empat menteri yaitu menteri pendidikan dan kebudayaan, menteri agama, menteri kesehatan dan menteri dalam negeri Republik Indonesia nomor 03/KB/2020, nomor 612 tahun 2020, nomor HK.01.08/Menkes/502/2020 dan 119/4536/SJ tentang panduan penyelenggaraan pembelajaran pada tahun ajaran 2020/2021 dan tahun akademik 2020/2021 di masa pandemic Corona virus disease 2019 (Covid-19), (salinan keputusan bersama 4 menteri, 2020; 01), keputusan Bupati Bantul nomor 501/2020 tentang perpanjangan keenam status tanggap darurat bencana corona virus disease 2019 (Covid-19) di kabupaten Bantul (salinan keputuan Bupati Bantul). Semua itu dilakukan karena menjelang awal 2021, gejala penyebaran Covid-19 belum juga turun.

Pembelajaran jarak jauh adalah pendekatan pembelajaran yang pada pelaksanaanya tidak bertatap muka secara langsung dalam pembelajaran (Rosali et al., 2020). Pembelajaran ini biasanya menggunakan media berbasis internet. Contohnya adalah video animasi, youtube, google classroom, whatsApp, google meet/zoom dan lain sebagainya (Didik, 2020). Sistem pembelajaran jarak jauh menuntut adanya kreativitas dan kompetensi guru agar mampu melaksanakan pembelajaran yang efektif (Aji, 2020).

Pelaksanaan pembelajaran jarak jauh menimbulkan masalah baru dalam dunia pendidikan. Anak-anak mulai merasa bosan belajar daring, kondisi dan iklim belajar menjadi kurang kondusif, dan guru kurang mampu menguasai teknologi pembelajaran yang baik (Yulia, 2020), agar motivasi belajar siswa tetap tinggi (Fitriyani et al., 2020), sehingga pembelajaran jarak jauh pada masa pandemi Covid-19 tetap efektif. Selain itu, kepala sekolah harus mampu mengatasi masalah hilangnya kesempatan anak-anak untuk dapat bersosialisasi dan mengembangkan karakter sosial meraka di sekolah, terutama masalah perkembangan moral pada peserta didik (Hasanah, 2019). Kondisi ini menuntut seorang Kepala sekolah agar lebih kreatif dan mampu mengembangkan kepemimpinan agar mampu mempengaruhi dan menggerakkan orang-orang untuk mencapai tujuan organisasi (Romlah, 2016).

Sebagai seorang pemimpin, Kepala sekolah harus mampu menghormati perbedaan, mensinergikan perbedaan sehingga dapat membangun kekuatan (Ekosiswoyo, 2016). Kepala sekolah harus mampu menggerakkan orang-orang dengan baik dengan usaha yang optimal sehingga tujuan organisasi yang dipimpinnya dapat tercapai dengan baik dan maksimal. Semua usaha kepala sekolah merupakan kemampuan seseorang kepala sekolah dalam mempengaruhi individu atau kelompok yang dipimpinya melalui suatu proses untuk mencapai tujuan organisasi (Uriatman, 2015.). Dalam usaha mencapai tujuan yang ditetapkan tersebut, pemimpin dan kelompok harus saling bekerjasama (Ekosiswoyo, 2016).

Seorang kepala sekolah dianggap sangat penting karena Kepala sekolah merupakan ujung tombak kepemimpinan di sekolah, yang bertanggung jawab kemajuan sekolah (Kartiwi, 2020). Pada aspek yang lebih sederhana, tanggung jawab seorang kepala sekolah 
berhubungan dengan masalah teknis dan non teknis (Hutscins, 2020). Pada tataran teknis, kepala sekolah dituntut mampu berperan dalam membawa kemajuan sekolah melalui pola manajerial (Purwanto, 2016), serta pengembangan pembelajaran secara optimal dalam menentukan kebijakan dan mengarahkan untuk mengatur pelaksanaan pembelajaran supaya tercipta iklim yang kondusif selama pembelajaran jarak jauh di masa Covid-19 (Lurita Sari, 2020)

Kondisi dan model pembalajaran jarak jauh (Murray et al., 2020), menuntut agar para Kepala sekolah dapat mengkondisikan guru-guru agar dapat merancang metode dan media yang cocok serta bervariasi untuk setiap materi sehingga dapat mewujudkan hasil pendidikan yang berkualitas. Kepala sekolah bertugas melakukan supervisi, mengkoordinir, membimbing, memotivasi, memimpin dan mengoreksi kepada guru untuk dapat mengetahui sejauh mana kompetensi guru tersebut terutama dalam mengajar dan menyampaikan materi kepada siswa (Ilyavi, 2019). Upaya peningkatan kualitas dan produktivitas dalam bidang apapun, tidak terlepas dari sistem menajemen yang dikembangkan, sehingga faktor kepemimpinan sangat berperanan penting dan menentukan arah kebijakan. Machado \& Chung (2015) membuktikan bahwa peran kepala sekolah dalam proses mengintegrasikan teknologi di kelas dan berkeyakinan yang kuat dari kepala sekolah tentang kurangnya pelatihan teknis dan kompetensi guru yang menghalangi sekolah dari integrasi teknologi (Abid Azhar \& Iqbal, 2018). Maka seorang Kepala sekolah berkewajiban memberikan pelatihan teknis kepada guru sehingga guru lebih handal menggunakan teknologi terutama di masa covid 19 (Saleh, n.d.).

Daryanto (2001) menyebutkan bahwa salah satu tantangan terberat bagi kepala sekolah pada masa pandemi Covid-19 adalah kewajiban untuk dapat harus menciptakan iklim pembelajaran yang kondusif. Kepala sekolah harus melibatkan bawahan (guru dan karyawan) dalam keikutsertaan dalam proses pengambilan keputusan menjalankan menejemen sekolah untuk menciptakan iklim pembelajaran yang kondusif pada masa Covid-19. Kepala sekolah juga perlu bekerjasama dengan orang tua untuk menjaga lingkungan sekitar rumah agar pembelajaran on line lebih kondusif terutama pendampingan orang tua di waktu pembelajaran efektif maupun saat ujian ujian. Semua itu memerlukan kemampuan kepemimpinan yang memadai.

Berdasarkan hasil pengamatan yang dilakukan di SD Muhammadiyah Blawong 2, Kabupaten Bantul, Daerah Istimewa Yogyakarta (DIY), merupakan salah satu sekolah yang berhasil membangun iklim belajar yang kondusif pada masa pandemi Covid-19. Proses pembelajaran tetap berjalan dengan baik dan terukur hasilnya. Sekolah ini juga berhasil melakukan Kerjasama yang baik dengan orang tua siswa, sehingga sekolah dapat mengatasi berbagai kendala pembelajaran jarak jauh yang dirasakan oleh para peserta didik. Keberhasilan tersebut merupakan sebuah best practice kepemimpinan kepala sekolah yang dapat berguna bagi para kepala sekolah lainnya, tentang tata cara pengelolaan guru serta proses membangun kolaborasi dengan para orang tua yang efektif. Adapun penelitian ini bertujuan untuk mengeksplorasi kepemimpinan kepala SD Muhammadiyah Blawong 2 dalam membangun iklim pembelajaran yang efektif pada masa Covid-19, agar menghasilkan sebuah gambaran nyata mengenai best practice kepemimpinan kepala sekolah yang efektif dalam membangun iklim belajar yang kondusif. Pengetahuan mengenai hal tersebut sangat diperlukan oleh para pengelola sekolah sebagai solusi terhadap kondisi pandemi yang mengharuskan semua siswa belajar melalui sistem pembelajaran jarak jauh. 


\section{Metode Penelitian}

Penelitian ini menggunakan metode penelitian kualitatif dimana penelitian kualitatif sebagai metode ilmiah yang bersifat deskriptif digunakan dan dilaksanakan oleh peneliti dalam bidang ilmu sosial termasuk juga ilmu pendidikan. Mengacu pada pendapat Moleong, (2012) pendekatan kualitatif adalah metode yang digunakan untuk menganalisis data melalui cara mendeskripsikan data dengan kata-kata untuk menafsirkan dan menginterpresestasikan data dari hasil kata-kata atau lisan orang lain dan observasi lingkungan. Penelitian ini menggunakan latar belakang alamiah apa adanya, tanpa dimanipulasi sehingga proses pelaksanaan lebih dipentingkan daripada hasil, dan penekanannya pada implementasi pelaksanaan pembelajaran jarak jauh secara kondusif di masa Covid-19 di SD Muhammadiyah Blawong 2, Kabupaten Bantul, DIY Partisipan penelitian merupakan seseorang atau sesuatu berkaitan penelitian yang ingin diperoleh keterangannya untuk mendukung penelitian (Amirin, 2000). Partisipan dalam penelitian ini terdiri dari kepala sekolah, tiga orang guru, ketua komite, dan tiga orang wali siswa. Partisipan dalam penelitian ini adalah sebagai berikut:

a) Kepala Sekolah SD Muhammadiyah Blawong 2 yaitu untuk mendapatkan programprogram khusus yang dilakukan sekolah di masa pandemi, dan kendala-kendala yang ditemui saat pelaksanaan PJJ di SD Muhammadiyah Blawong 2 serta bagaimana pihak sekolah mencari solusinya.

b) Guru/wali kelas SD Muhammadiyah Blawong 2 untuk mendapatkan informasi tentang PJJ, tingkat kedisiplinan peserta didik dan pelaksanaan program pendidikan karakter.

c) Orang tua peserta didik untuk mendapatkan konfermasi program sekolah, proses pengambilan kebijakan sekolah dan pelaksanaan kebijakan baik di sekolah maupun di rumah selama masa Covid-19 terutama pembelajaran jarak jauh.

Dalam penelitian ini menggunakan dua data yaitu data primer dan data sekunder. Data primer yaitu data yang diamati dari sumbernya langsung, diamati dan dicatat untuk pertama kalinya Margono (2000). Data primer diperoleh dari hasil wawancara dengan kepala sekolah, guru dan beberapa orang tua di SD Muhammadiyah Blawong 2. Data sekunder adalah data yang didapat dari catatan-catatan dan dokumen-dokumen yang dimiliki sekolah terkait proses penegmbangan iklim sekolah yang efektif pada masa Covid-19 ini. Proses pengumpulan data dalam penelitian ini dilaksanakan melalui 3 cara yaitu melalui wawancara individual mendalam, observasi lingkungan, dan analisis dokumen. Tiga cara pengambilan data ini sekaligus dilakukan untuk melakukan tranggulasi data agar data yang dikumpulkan merupakan data yang objektif (Danim, 2002). Proses wawancara yang dilakukan dengan kepala sekolah, guru/wali kelas dan orang tua peserta didik SD Muhammadiyah Blawong 2 secara terpisah masing-masing.

Proses analisis data menggunakan teknik analisis data kualitatif (Williamson et al., 2018) yaitu terdiri dari: 1). Reduksi Data. Data yang diperoleh dari lapangan jumlahnya cukup banyak, maka untuk itu perlu dicatat dan diteliti secara rinci, dan dibutuhkan analisis data melalui reduksi data. 2). Penyajian Data (display). Setelah data direduksi, maka langkah selanjutnya adalah disajikan data. Dalam penelitian ini penyajian data disajikan dengan uraian teks yang bersifat narasi. Tujuan dalam proses display data agar hasil penelitian ini mudah untuk difahami. 3) Verifikasi. Langkah ketiga dalam analisis data adalah verifikasi atau penarikan kesimpulan. Dengan langkah ini maka diharapkan dapat menjawab rumusan masalah yang telah ditetapkan sehingga menjadi suatu masalah yang sudah jelas dan mungkin dapat menemukan temuan baru yang sebelumnya belum pernah ada. 


\section{Hasil Penelitian dan Pembahasan}

Berdasarkan hasil analisis data penelitian ini, ditemukan ada beberapa sikap kepemimpinan kepala sekolah yang menjadi latar belakang suksesnya sekolah dalam mengembangkan iklim belajar yang kondusif, sebagai berikut:

\section{1) Sikap Adaptif}

Kepala sekolah mempunyai anggapan bahwa Proses belajar mengajar di SD Muhammadiyah Blawong 2 tidak dapat diselenggarakan di sekolah secara luar jaringan (luring) dan guru tidak bisa memberikan materi dan latihan kepada peserta didik dikarenakan adanya wabah Covid-19, sehingga Kepala Sekolah memiliki pandangan bahwa di SD Muhammadiyah Blawong 2 diperlukan adanya kebijakan baru tentang proses belajar mengajar di masa Covid-19. Hal ini ditunjukkan oleh pernyataan Kepala sekolah sebagai berikut:

"SD Muhammadiyah Blawong 2 Sekolah berusaha melaksanakan pembelajaran Jarak Jauh sesuai peraturan baik dari Pemerintah maupun Yayasan, tetapi diseuaikan dengan kondisi dan kemampuan orang tua siswa. Khusus di kelas V dan VI karena program awal unggulan jadi semua siswa digratiskan untuk pembayaran sekolah, dengan melihat kondisi seperti itu maka pihak sekolah tidak dapat mememaksakan untuk melaksanakan PJJ on line daring dengan fasilitas internet yang bagus. orang tua khususnya kelas V dan VI secara ekonomi rata-rata menengah ke bawah, maka pihak sekolah mempunyai kebijaksanan tetap melaksanakan PJJ dengan sistem Luring dan daring disesuaikan dengan kondisi orang tua. Tidak semua siswa mempunyai gedjet sendiri mereka tergantung gedjet orang tua, bahkan ada siswa maupun orang tua tidak mempunyai gedjet yang sport terhadap WA yang digunakan untuk mengirimkan materi maupun tugas dari sekolah, disinilah pihak sekolah dituntut kreatif untuk melaksanakan pembelajaran jarak jauh tetap terlaksana secara kondusif, materi tetap bisa di terima dengan baik sehingga tujuan pembelajaran tetap tercapai dengan hasil yang baik dan bermutu" (senin, 16/11/2020; 09.30)"

Pernyataan tersebut diperkuat oleh Guru yang menyatakan hal yang sama. Berikut ini pernyataan relevan dari Guru (G1), sebagai berikut :

“....berdasar anjuran Bapak Kepala sekolah, KBM tetap dilaksanakan di rumah dengan menggunakan media yang dapat dengan mudah dilaksanakan yang penting materi bisa tersampaikan kepada anak-anak. Wali kelas akan memberitahu orang tua tentang materi dan tugas-tugas yang harus dilaksanakan anak-anak di rumah. Selain itu GuruGuru selaku wali kelas V tetap berusaha agar semua anak didiknya dapat secara aktif mengikuti PJJ salah satunya bekerjasama dengan PPL dari UAD yang berada di SD Muhammadiyah Blawong 2, juga mencoba dengan WA dan penilaian harian dengan google form. Setiap saat Guru-guru selalu mengingatkan siswa melalui WA grup kelas untuk sholat, berdoa, belajar, mengaji/tadarus serta membantu orang tua. (Sabtu, 28 November 2020 jam 10.00)

Pelaksanaan pembelajaran jarak jauh, terkendali dengan baik karena semua guru telah mendapatkan pengarahan dari kepala sekolah bahwa semua pendidik harus memiliki sikap adaptif terhadap semua perubahan. Hasilnya adalah meskipun terjadi pergantian pola pembelajaran di SD Muhammadiyah Blawong 2, ternyata tetap berjalan dengan baik. Menurut G2, (pengajar kelas IV) iklim pembelajaran tetap berjalan kondusif berkat sikap dan pemahaman kepala sekolah yang segara memberikan kebijakan-kebijakan adaptif terkait 
pembelajaran jarak jauh pada masa Covid-19. Sebagai seorang guru, G2 mengakui betapa pentingnya iklim belajar yang baik. Berikut ini pernyataan G2:

"siswa yang mempunyai kondisi pembelajaran yang baik dan kondusif cenderung mempunyai sikap yang jujur dan disiplin juga dalam PJJ di masa covid 19, ternyata tidak berbeda jauh seperti yang diungkapkan G1 selaku wali kelas $\mathrm{V}$ bahwa kelasnya juga bagi siswa yang kondisi dan pengawasan orang tua kondusif maka akan mempengaruhi tingkat kejujuran dan disiplin siswa apalagi di masa covid 19. Menurut beliau masih ada beberapa kendala yang dihadapi siswa untuk meningkatkan PJJ, terlihat dari hasil rekapan yang peneliti dapatkan (Sabtu, 28 November 2020 jam 11.00).

Pelaksanaan pembelajaran jarak jauh untuk kelas VI sedikit ada perbedaan meskipun tetap menjaga protokol kesehatan, dikarenkan kelas VI akan mengikuti ujian akhir maka Kepala sekolah sedikit memberikan kelonggaran untuk kelas VI. Berikut pernyataan G3:

"selama PJJ pembelajaran tetap memakai daring dan luring terkadang juga ada tatap muka seminggu sekali tetapi untuk kali ini sementara belum karena ada surat ada surat edaran dari bupati kalu tidak diperbolehkan tetap muka. Beberapa kendala yang dihadapi siswa untuk PJJ yaitu keterlambatan mengirimkan maupun menyetorkan tugas dan sebagian orang tua tidak membimbing putra-putrinya juga HP tidak support serta tidak setiap anak mempunyai HP sendiri (Senin, 30 November 2020, pukul 08.00)

Sikap kepemimpinan yang adaptif terbukti mampu menggugah kesadaran para guru dan orang tua untuk menyadari adanya perubahan model pembelajaran pada masa darurat Covid19. Hal tersebut sejalan dengan hasil penelitian (Dunn, 2020), yang menyebutkan bahwa kepemimpinan adaptif merupakan jenis kepemimpinann yang relevan untuk mengatasi permasalahan pendidikan pada masa Covid-19. Bentuk sikap kepemimpinan adaptif di sekolah adalah dengan adanya kebijakan-kebijakan dalam pemilihan media pembelajaran pada masa karantina bagi para peserta didik agar pembelajaran tetap berjalan secara efektif. Oleh karena itu, pada masa pandemi Covid-19 membutuhkan kecerdasan dan kebijakan untuk mencari media yang cocok sesuai dengan jenjang pendidikan dari tingkat usia dini sampai perguruan tinggi (Atsani, 2020).

\section{2) Sikap Demokratis}

Dalam upaya membangun iklim belajar yang kondusif, kepala sekolah menunjukan sikap kepemimpinan yang demokratis. Hal ini tampak dari perilaku kepemimpinan dalam hal untuk menetapkan keputusan tentang bentuk pembelajaran yang cocok di musim pandemi Covid-19 bagi semua siswa. Hal yang dilakukan oleh kepala sekolah setelah mendapatkan surat edaran dari Menteri, Dinas dan Majlis Muhammadiyah, tidak langsung mengambil kebijakan sendiri, melainkan mengundang semua stakeholder untuk mengadakan pertemuan tentang bagaimana pelaksanaan KBM di masa Covid-19. Hal tersebut diperkuat adanya notulen rapat tertanggal selasa, 13 Juli 2020 jam 08.00-09.30 dengan agenda teknis pembelajaran selama Covid-19

Dari catatan kesimpulan notulen hasil rapat wali murid kelas V : Sekolah meminta pendapat dari orang tua siswa tentang pelaksanaan PJJ yang akan dimulai minggu depan, menentukan media untuk pembelajaran PJJ, apakah on line atau luring, orang tua mengusulkan dua-duanya tetapi lebih sering dengan luring disesuaikan keadaan orang tua, karena tidak mungkin semua keluarga SD Muhammadiyah Blawong 2 menggunakan on line apalagi zoom. (Rabu, 30 Desember 2020: 07:32 WIB). Hal tersebut sejalan dengan pernyataan WS 1: 
"beliau [orang tua murid] juga diundang dalam rapat hari/tanggal selasa, 13 juli 2020 jam 08.00-09.30 wib untuk mewakili kelas VI. Sekolah meminta pendapat orang tua untuk membuat kebijakan menentukan cara penyampaian materi pembelajaran jarak jauh, apakah memakai on line atau luring. Kebanyakan menggunakan luring karena sesuai keadaan orang tua, sebab tidak mungkin semua keluarga SD Muhammadiyah Blawong 2 menggunakan on line apalagi zoom, maka menggunakan system luring untuk membantu siswa yang HPnya tidak sport dan jika pembelajaran online tidak dapat berjalan karena kuarngnya sinyal, karena tidak semua mempunyai HP sendiri dan pembengkakan kuota data malah nanti tidak bisa membayar yang lain. Keputusan rapat bahwa orang tua yang harus mengambil tugas ke sekolah selanjutnya siswa mengerjakan dirumah kemudian orang tua mengumpulkan kembali ke sekolah sebab siswa tidak boleh datang ke siswa. (kamis, 24 Des. 2020: 10:10 WIB).

Menurut WS 2 (wakil dari kelas V) bahwa keputusan untuk melaksanakan pembelajaran daring dan juga system pembelajaran jarak jauh model luring, merupakan hasil usulan orang tua murid. Berikut ini pernyataan WS2 mengenai hal tersebut:

"Para wali murid mengusulkan mengunakan yang memungkinkan diikuti semua warga sekolah, jika pakai cuma pakai zoom belum tentu HP orang tua/wali bisa suport untuk zoom. Mayoritas mengusulkan luring yaitu untuk tugas di ambil seminggu sekali. Mengambil dan mengumpulkan tugas setiap hari senin atau sabtu" (jum' at, 25 Des 2020: 15:03 wib by WA)"

Sikap demokratis yang dilakukan oleh kepala sekolah telah berhasil membangun rasa memiliki dari setiap stakeholder yang ada di sekolah, sehingga setiap keputusan yang diambil menajdi keputusan bersama untuk dipatuhi bersama. Hal ini sejalan dengan hasil penelitian Deliper lase, dkk, yang menyatakan bahwa para orang tua memiliki kesan positif terhadap keterbukaan dan sikap demokratis pihak sekolah dalam mengambil keputusan bentuk pembelajaran yang efektif pada masa pandemic Covid-19 ini (Lase et al., 2020).

\section{3) Mengutamakan kerjasama}

Kepala sekolah selalu mengutamakan kerjasama antar semua unsur pendidikan di sekolah maupun instansi terkait dalam menyelesaikan setiap permasalahan. Hal ini tampak dari berbagai kebijakan yang dikeluarkan dan selalu melibatkan beberapa pihak untuk melaksanakannya. Sebagai contoh adalah Kepala sekolah membentuk beberapa tim penanggulangan Covid di sekolah yaitu membentuk TIM satgas Covid-19, TIM penyusunan POS pembelajaran jarak jauh, dan program kurikulum dan pengembangan SD Muhammadiyah Blawong 2 yang melibatkan seluruh stake holder dan membagi pekerjaan sesuai dengan bidang keahlian. Dalam konteks ini, kepala sekolah berupaya menggalang Kerjasama dengan banyak pihak, termasuk dengan puskesmas, keamanan, dan juga komite sekolah.

Sikap kerjasama yang dilakukan oleh Kepala Sekolah berhasil menciptakan rasa kekeluargaan yang kuat dari setiap warga sekolah, sehingga setiap tugas untuk kemajuan sekolah dapat dilaksanakan secara gotong-royong penuh rasa keiklasan. Hal ini sejalan dengan hasil penelitian (Kington, 2015) yang menyatakan bahwa sikap kepemimpinan kepala sekolah memiliki dampak yang signifikan terhadap keterlibatan orang tua dalam proses pendidikan para siswa.

\section{4) Sikap Adil}

Kepala Sekolah mempunyai sikap yang adil bagi semua Guru dan karyawan, sehingga semua stakeholder diperlakukan sama dalam menentukan kebijakan baik pembagian tugas 
maupun perhatian. Menurut pengakuan salah satu wali siswa, kepala sekolah memperlakukan seluruh siswanya secara adil, begitupun perlakuan kepala sekolah terhadap semua wali murid. Tidak ada perbedaan sikap terhadap siapapun. Hal itu menimbulkan rasa nyaman dan tenang bagi para wali murid. Pernyataan tersebut didukung oleh pernyataan G2 yang menyatakan bahwa kepala sekolah selalu bersikap adil dan terbuka kepada semua orang, baik pada guru, siswa, maupun orang tua murid. Hal ini yang menyebabkan semua orang mendukung semua programnya.

Sikap adil yang dilakukan oleh Kepala Sekolah berhasil menciptakan rasa nyaman dari setiap warga sekolah, sehingga setiap tugas untuk kemajuan sekolah dapat dilaksanakan secara bertanggung jawab. Hal ini sejalan dengan hasil penelitian Cheryl, dkk (2003) yang menyebutkan bahwa sikap adil yang dilakukan oleh seorang pemimpin dapat menimbulkan terbentuknya lingkungan kerja yang kondusif, rasa nyaman dari para pekerja, dan munculnya perasaaan dihargai. Sikap pemimpin yang adil memiliki dampak psikologi yang signifikan.

Sikap adil tersebut menunjukan bahwa Organisasi dan pimpinan sekolah semakin sadar bahwa mereka menghadapi masa depan perubahan yang cepat dan kompleks. Gelombang ketidakpastian yang berorientasi masa depan ini, ditambah dengan tuntutan individu untuk peningkatan partisipasi di semua tingkat organisasi, telah mengubah persepsi kepemimpinan secara dramatis, khususnya terkait dengan peran masing-masing yang dimainkan oleh pemimpin dan pengikut. Hampir semua teori kepemimpinan didasarkan pada kepentingan relatif yang ditugaskan kepada pemimpin versus pengikut dalam pencapaian misi. Namun orang mempertanyakan apa efeknya terhadap sikap dan perilaku karyawan. Meskipun ada banyak faktor yang mempengaruhi sikap dan perilaku karyawan, penelitian sampai saat ini menunjukkan bahwa faktor-faktor tersebut dipengaruhi oleh gaya kepemimpinan. Dalam upaya untuk memahami efektivitas memahami efektivitas kepemimpinan, peneliti telah mempelajari dua jalur utama teori.

\section{5) Sikap Preventif}

Kepala sekolah juga memiliki sikap preventif, terutama dalam mengantisipasi munculnya efek buruk dari penyebaran Covid-19. Kepala sekolah beserta staff memutuskan untuk Menyusun POS pembelajaran jarak jauh model luring yang tetap mengutamakan Kesehatan dan protocol Covid-19. Berdasarkan POS menjelaskan bahwa pelaksanaan proses belajar mengajar di SD Muhammadiyah Blawong 2 harus mematuhi protocol kesehatan sebagai berikut:

a) Prosedur Operasional Standar (POS) Pemantauan dan Pelaporan Kesehatan warga satuan Pendidikan (Pos Kedatangan warga sekolah)

b) Prosedur operasional standar (POS) bagi orang tua/wali pengantar/penjemput siswa di SD Muhammadiyah Blawong II

c) Prosedur Operasional Standar (POS) Kegiatan Belajar Mengajar Tatap Muka di SD Muhammadiyah Blawong 2

d) Prosedur Operasional Standar (POS) Kegiatan Ekstra-kurikuler di SD Muhammadiyah Blawong 2

e) Prosedur Operasional Standar (POS) Sterilisasi dan Disinfeksi Rutin Sarana dan Prasarana di SD Muhammadiyah Blawong 2

f) Prosedur Operasional Standar (POS) Pengaturan Kantin, Pedagang kaki lima dan warung makanan di sekitar lingkungan SD Muhammadiyah Blawong 2

Sikap preventif yang dilakukan oleh Kepala Sekolah berhasil menciptakan rasa aman, nyaman dari setiap warga sekolah, sehingga pelaksanaan PJJ di SD Muhammadiyah Blawong 2 dapat terselenggara sesuai kebijakan yang sudah ditetapkan agar terjaga kesehatan dan penularan virus Covid-19 tidak. Hal ini sejalan dengan hasil penelitian (Aji, 2020) yang 
menyatakan pembelajaran daring dinilai efektif jika diterapkan pada masa pandemi Covid-19, karena lebih aman secara Kesehatan fisik bagi para siswa.

Hasil penelitian ini menunjukan berbagai sikap kepemimpinan kepala sekolah yang efektif dalam membangun lingkungan belajar yang kondusif pada masa pembelajaran jarak jauh, sangat erat kaitannya dengan sikap-sikap kepemimpinan yang lebih mengutamakan penyelarasan sikap, baik dengan kondisi lingkungan maupun dengan orang-orang yang terlibat di dalam Lembaga Pendidikan yang dikelola. Kondisi ini dapat menjadi alternatif pemilihan gaya kepemimpinan bagi para kepala sekolah dasar dalam membangun lingkungan belajar yang efektif, meskipun belum tentu gaya tersebut sesuai untuk situasi dan kondisi yang berbeda. Hal ini mengacu pada hasil review yang dilakukan oleh (Nawaz \& Khan, 2016) bahwa teori gaya mengakui pentingnya keterampilan kepemimpinan tertentu yang diperlukan yang berfungsi sebagai pemungkin bagi seorang pemimpin yang melakukan suatu tindakan sambil menggambar paralelnya dengan kapasitas sebelumnya dari pemimpin, sebelum tindakan tertentu itu sambil menyarankan bahwa setiap individu memiliki gaya kepemimpinan yang berbeda dengan yang dia rasa paling puas. Seperti gaya yang tidak cocok untuk semua kepala sekolah, demikian pula satu gaya tidak dapat efektif dalam semua situasi (Nawaz \& Khan, 2016). Dalam penelitian ini, tampak nyata bahwa dalam merencanakan dan membangun iklim sekolah yang kondusif, diperlukan kemampuan kepemimpinan kepala sekolah yang memadai, baik berupa kemampuan yang bersifat teknis maupun strategi. Hal ini sesuai dengan pernyataan (Lee \& Taylor, 2014; Obama et al., 2015) bahwa kepala sekolah merupakan seseorang yang memiliki peran dalam proses pengembangan mutu sekolah, seperti pengembangan kemampuan akademik siswa, iklim belajar, dan perkembangan psikologis siswa, oleh sebab itu kepala sekolah harus mampu mengembangkan kepemimpinan yang kreatuf dan inovatif.

\section{Kesimpulan}

Berdasarkan hasil penelitian dapat disimpulkan bahwa keberhasilan kepala sekolah dalam menjalankan tugas kepemimpinannya membangun lingkungan belajar yang kondusif di masa pandemi Covid-19 adalah dengan menerapkan gaya kepemimpinan yang adaptif, mengutamakan Kerjasama, bersikap adil, dan memiliki sikap prefevtif. Hal tersebut menunjukan bahwa kepala sekolah harus dapat membuat kebijakan yang dapat melindungi semua warga sekolah secara intern dan ektsern yang tertuang dalam peraturan operasional sekolah untuk membangun iklim belajar yang kondusif.

Pembelajaran Jarak Jauh di SD Muhammadiyah Blawong 2 dilaksanakan secara daring dan luring dari rumah disesuaikan kondisi keluarga dan kebijakan sekolah karena tidak semua orang tua memfasilitasi gawai dan pulsa yang memadai untuk PJJ, maka sekolah tetap berusaha mengadakan pembelajaran jarak jauh dengan sebaik-baiknya agar tujuan sekolah dapat terwujud meskipun di masa Covid-19. Kepala SD Muhammadiyah 2 Blawong berhasil mendapatkan dukungan dari para orang tua siswa dalam menyukseskan seluruh programnya. Dalam konteks ini, dukungan orang tua yang diterima oleh sekolah menjadi modal yang luar biasa bagi penyelenggaraan proses pembelajaran dan pembentukan iklim belajar yang kondusif.

\section{Saran}

Adapun saran yang disampaikan atas dasar temuan penelitian ini adalah (1) Bagi kepala sekolah agar lebih meningkatkan kreativitas yang mampu mengakomodir berbagai perubahan yang ada. Hasil penelitian ini menunjukan sebuah best practice kepemimpinan yang terbukti efektif dalam membangun iklim belajar yang kondusif karena kepala sekolah memahami 
kondisi fisik maupun psikologis semua warga sekolah. Hal tersebut layak untuk dijadikan sebagai sebuah contoh bagi para kepala sekolah yang lain. (2) Bagi para orang tua hendaknya aktif melakukan komunikasi efektif dengan pihak sekolah agar terjadi kesamaan pemahaman antara guru dan orang tua sehingga dapat membangun iklim belajar yang kondusif untuk anak-anak.

\section{Daftar Pustaka}

Abid Azhar, K., \& Iqbal, N. (2018). Effectiveness of Google Classroom: Teachers' Perceptions. Prizren Social Science Journal, 2(2), 52-66.

Aji, R. H. S. (2020). Dampak Covid-19 pada Pendidikan di Indonesia: https://doi.org/10.15408/sjsbs.v7i5.15314

Amirin, T. M. (2000). Menyusun rencana penelitian. 2000.

Atsani, K. L. G. M. Z. (2020). Transformasi Media Pembelajaran Pada Masa Pandemi Covid-19. 1, 82-93.

Citra Resmi, U. D., \& Hasanah, E. (2020). Best Practice Leadership of The Principal in Covid-19 Prevention Primary School at SD Muhammadiyah Purbayan. Randwick International of Education and Linguistics Science Journal. https://doi.org/10.47175/rielsj.v1i3.150

Didik, P. (2020). Jurnal Pendidikan dan Pembelajaran Bahasa Indonesia Vol 9 No 2 , Oktober 2020 Jurnal Pendidikan dan Pembelajaran Bahasa Indonesia Vol 9 No 2 , Oktober 2020. 9(2).

Dunn, R. (2020). International Studies in Educational Administration. July.

Ekosiswoyo, R. (2016). Kepemimpinan Kepala Sekolah yang Efektif Kunci Pencapaian Kualitas Pendidikan. Jurnal Ilmu Pendidikan, 14(2), 76-82.

Fitriyani, Y., Fauzi, I., \& Sari, M. Z. (2020). Motivasi Belajar Mahasiswa Pada Pembelajaran Daring Selama Pandemik Covid-19. Jurnal Kependidikan: Jurnal Hasil Penelitian Dan Kajian Kepustakaan Di Bidang Pendidikan, Pengajaran Dan Pembelajaran. https://doi.org/10.33394/jk.v6i2.2654

Hasanah, E. (2019). Perkembangan moral anak SD berdasarkan teori Kohlberg. Jipsindo, 6(2), 131-145. https://doi.org/https://doi.org/10.21831/jipsindo.v6i2.28400

Hasim, W., \& Hasanah, E. (2020). The Role of Principal Leadership in Preventing COVID19 Transmission at SMA Muhammadiyah 2 Karang Tengah Buay Madang Timur Indonesia. Asian Journal of Education and Social Studies, 11(1), 1-10. https://doi.org/10.9734/ajess/2020/v11i130279

Herliandry, L. D., \& Suban, M. E. (2020). Jurnal Teknologi Pendidikan Pembelajaran Pada Masa Pandemi Covid-19. 22(1), 65-70.

Hutscins, S. D. (2020). Back to school 2020: Planning for uncertainty. ASHA Leader.

Ilyavi, Y. (2019). Correlational study of principal leadership styles and teacher's emotional exhaustion, depersonalization, and feeling of reduced personal accomplishment. In Dissertation Abstracts International: Section B: The Sciences and Engineering.

Kartiwi, A. P. (2020). Principal transformational leadership in high school of central kalimantan. International Journal of Educational Management and Innovation. https://doi.org/10.12928/ijemi.v1i1.1514

Kington, A. (2015). The Impact of School Leadership on Parental Engagement: A Study of Inclusion and Cohesion. July 2013. https://doi.org/10.5296/ire.v1i1.3844

Lase, D., Ndraha, A., \& Harefa, G. G. (2020). Persepsi Orangtua Siswa Sekolah Dasar di Kota Gunungsitoli Terhadap Kebijakan Pembelajaran Jarak Jauh pada Masa Pandemi Covid-19. 
Lee, J., \& Taylor, M. S. (2014). Dual roles in psychological contracts: When managers take both agent and principal roles. Human Resource Management Review, 24(1). https://doi.org/10.1016/j.hrmr.2013.03.001

Murray, C., Heinz, M., Munday, I., Keane, E., Flynn, N., Connolly, C., Hall, T., \& MacRuairc, G. (2020). Reconceptualising relatedness in education in 'Distanced' Times. European Journal of Teacher Education. https://doi.org/10.1080/02619768.2020.1806820

Nawaz, A., \& Khan, I. U. (2016). Leadership Theories and Styles: A Literature Review Leadership Theories and Styles: A Literature Review. February.

Obama, M. O., Eunice2, L. A., \& Orodho, J. A. (2015). Effect of Principals' Leadership Styles on Students Academic Performance in Public Secondary Schools in Homa-Bay County, Kenya. IOSR Journal Of Humanities And Social Science Ver. VII, 20(3), 5160. https://doi.org/10.9790/0837-20375160

Purwanto, N. (2016). Strategi Dalam Menyiapkan Dan Membina Kepala Sekolah. Jurnal Manajemen Pendidikan UNY, 12(2), 112187.

Romlah. (2016). Manajemen Pendidikan Islam. Manajemen Pendidikan Islam, 1-232. https://doi.org/10.1017/CBO9781107415324.004

Rosali, E. S., Pendidikan, J., \& Universitas, G. (2020). Aktifitas pembelajaran daring pada masa pandemi covid -19. 1, 21-30.

Saleh, A. M. (n.d.). Problematika Kebijakan Pendidikan Di Tengah Pandemi Dan Dampaknya Terhadap Proses Pembelajaran Di Indonesia.

Uriatman, M. (n.d.). Upaya Kepala Sekolah Dalam Meningkatkan. 822-827.

Williamson, K., Given, L. M., \& Scifleet, P. (2018). Qualitative data analysis. In Research Methods: Information, Systems, and Contexts: Second Edition. https://doi.org/10.1016/B978-0-08-102220-7.00019-4

Yulia, H. (2020). Online Learning to Prevent the Spread of Pandemic Corona Virus in Indonesia. ETERNAL (English Teaching Journal). https://doi.org/10.26877/eternal.v11i1.6068 